\title{
ANALISIS KADAR PROTEIN PADA ULAT SAGU (Rhynchophorus ferrugineus) ASAL KABUPATEN HALMAHERA TIMUR MALUKU UTARA DENGAN METODE KJELDAHL
}

\author{
Harti Widiastuti, Chakrawaty M. Kisan
}

Fakultas Farmasi Universitas Muslim Indonesia Makassar

Email : harti_widiastuti@yahoo.com

\begin{abstract}
Analysis of Protein Levels In Sago Worm (Rhynchophorus ferrugineus) East Halmahera, North Maluku regency with Kjeldahl Method Has done research on the analysis of protein content in sago (Rhynchophorus ferrugineus) from East Halmahera in North Maluku kjeldahl method. This study aims to obtain scientific data about the protein content in sago (Rhynchophorus ferrugineus). This research includes testing levels of total nitrogen and non protein nitrogen method kjeldahl on sago(Rhynchophorus ferrugineus). Research results showed that the protein content in sago (Rhynchophorus ferrugineus) Originof East Halmahera in North Maluku is $4.0575 \%$.
\end{abstract}

Key words : Protein, Ulat Sagu.

\section{PENDAHULUAN}

Kata protein berasal dari proteus atau protos yang berarti pertama atau utama. Protein adalah senyawa organik yang berat molekulnya tinggi, mengandung unsur $\mathrm{C}, \mathrm{H}, \mathrm{O}$ dan $\mathrm{N}$. serta unsur lainnya seperti $S$ dan $P$ yang membentuk unitunit asam amino dalam protein maupun hubungan antara asam amino yang satu dengan yang lainnya. Asamasam amino ini saling dihubungkan oleh suatu ikatan yang disebut ikatan peptida (-CO-NH) (Alfonsine,1985).

Protein digunakan sebagai sumber energi, jika karbohidrat dan lemak tidak mencukupi. Tubuh bisa membentuk cadangan protein, meski sangat kecil. Protein juga berperan sebagai cadangan energi. Fungsi protein adalah sebagai pembangun tubuh, pemberi tenaga (energi), sebagai pengatur kelangsungan proses pencernaan di dalam tubuh, dan sebagai pengatur yang melancarkan keluar masuknya cairan nutrien dan metabolik ke seluruh darah (Sediaoetama, 2000).

Salah satu limbah dari hasil panen sagu adalah batang bagian pucuk pohon yang merupakan tempat bertelurnya kumbang merah kelapa, 
Analisis Kadar Protein Pada Ulat Sagu (Rhynchophorus ferrugineus) Asal Kabupaten Halmahera Timur Maluku Utara Dengan Metode Kjeldahl

larva dari kumbang ini dikenal dengan nama ulat sagu (Rhynchophorus ferrugineus), yang biasanya dikonsumsi oleh masyarakat Maluku dan Papua (Edrus, 2009).

Pertanaman sagu di Maluku umumnya berdekatan dengan tanaman kelapa, sehingga bila telur dalam limbah sagu tersebut menetas dan menjadi kumbang dikhawatirkan dapat menjadi hama pada tanaman kelapa, larva kumbang merah kelapa dikenal sebagai ulat sagu (Rhynchophorusferrugineus)

(Bustaman, 2008).

Ulat sagu belum dimanfaatkan secara komersial. Namun, masyarakat Papua dan Maluku yang mengusahakan pengolahan sagu sebagai sumber pendapatan, memanfaatkan ulat sagu untuk dikonsumsi. Pada daerah-daerah dengan sumber protein hewani yang sulit diperoleh, ulat sagu dapat menjadi alternatif sumber makanan berprotein tinggi (Bustaman, 2008).

\section{METODE PENELITIAN}

\section{Penyiapan Sampel}

Pada penelitian ini digunakan ulat sagu asal kabupaten halmahera timur maluku utara, ulat sagu didapat dari pohon sagu yang dipotong kemudian batangnya dibiarkan membusuk. Untuk mengambil ulat sagu, batang sagu tersebut dibongkar atau dibuka. Ditimbang ulat sagu, dimasukkan ke dalam tabung digest. Kemudian sampel ulat sagu tersebut yang telah ditimbang, dilakukan pengujian kadar protein.

\section{Penetapan Kadar Protein}

Cara Penetapan Kadar Protein dengan metode kjeldahl

\section{Kandungan Nitrogen Total}

Ditimbang sampel ulat sagu masing-masing sebanyak 5,6432 gram dan 6,1453 gram, ditambahkan asam sulfat $25 \mathrm{ml}$ dan selenium 2 gram. Didestruksi selama \pm 3 jam sampai larutan berubah warna menjadi bening. Didinginkan kemudian dimasukkan kedalam labu ukur dan diencerkan dengan air suling sampai $100 \mathrm{ml}$ lalu dikocok. Dipipet larutan tersebut sebanyak $10 \mathrm{ml}$ dan dimasukkan ke dalam labu alas bulat. Ditambahkan 15 $\mathrm{ml} \mathrm{NaOH} 40 \%$ dan diencerkan dengan aquadest sampai volumenya menjadi $100 \mathrm{ml}$ kemudian didestilasi. Disiapkan erlenmeyer yang di beri 10 $\mathrm{ml}$ asam borat $2 \%$, indikator metil merah dan indikator brom kresol green sebanyak 4 tetes gunanya untuk menampung hasil destilat. Dilakukan destilasi hingga diperoleh volume destilat sekitar $50 \mathrm{ml}$. Dititrasi dengan asam sulfat $0,0142 \mathrm{~N}$ sampai larutan berubah warna dari hijau menjadi 
Analisis Kadar Protein Pada Ulat Sagu (Rhynchophorus ferrugineus) Asal Kabupaten Halmahera Timur Maluku Utara Dengan Metode Kjeldahl

merah kecoklatan. Perhitungan kadar nitrogen total :

$\%$ kadar $=\frac{\mathrm{V} \times \mathrm{N} \times 14 \times \mathrm{Fp}}{\text { Berat sampel }(\mathrm{mg})} \times 100 \%$

Keterangan :

$\mathrm{Fp} \quad=$ Faktor pengenceran

$\mathrm{V} \quad=$ Volume titrasi sampel $(\mathrm{ml})$

$\mathrm{N}=$ Normalitas asam sulfat

$14=$ Berat ekivalen nitrogen

\section{Kandungan Nitrogen Non Protein (Bukan Protein)}

Ditimbang sampel ulat sagu masing-masing sebanyak 7,3050 gram, 6,5972 gram. Dimasukkan kedalam labu kjeldahl, ditambahkan 50 $\mathrm{ml}$ air suling dan beberapa butir batu didih. Didihkan selama 30 menit, dijaga jangan sampai kering.

Sementara hasil ekstrak masih panas, ditambahkan $2 \mathrm{ml}$ larutan aluminium potassium sulfat, campur hingga homogen. Kemudian dipanaskan kembali sampai mendidih. Disaring melalui kertas saring dengan menggunakan corong buchner.

Dimasukkan filtrat ke dalam labu alas bulat kemudian ditambahkan $15 \mathrm{ml}$
$\mathrm{NaOH} 40 \%$ dan diencerkan dengan aquadest sampai volumenya menjadi $100 \mathrm{ml}$, kemudian didestilasi. Dilakukan destilasi hingga diperoleh volume destilat sekitar $50 \mathrm{ml}$. Hasil destilat ditampung dengan menggunakan erlenmeyer yang didalamnya telah ditambahkan $10 \mathrm{ml}$ asam borat $2 \%$ dan indikator metil merah dan indikator brom kresol green sebanyak 4 tetes. Dititrasi dengan asam sulfat $0,0142 \mathrm{~N}$ sampai larutan berubah warna dari hijau menjadi merah kecoklatan. Perhitungan kadar nitrogen bukan protein :

$$
\% \text { kadar }=\frac{V \times N \times 14}{\text { Berat sampel }(\mathrm{mg})} \times 100 \%
$$

Keterangan :

$\mathrm{V}=$ = Volume titrasi sampel $(\mathrm{ml})$

$\mathrm{N}=$ Normalitas asam sulfat

$14=$ Berat ekivalen nitrogen

Perhitungan kadar protein :

( \% N Total - \% N non protein ) $\times \mathbf{6 , 2 5}$

Keterangan :

$6,25=$ Besarnya faktor perkalian $\mathrm{N}$ pada makanan

\section{HASIL PENELITIAN}

Tabel 1 : Hasil Analisis Kualitatif Protein

\begin{tabular}{cccc}
\hline Sampel & $\begin{array}{c}\text { Rata-Rata Nitrogen } \\
\text { Total }\end{array}$ & $\begin{array}{c}\text { Rata-Rata Nitrogen } \\
\text { Non Protein }\end{array}$ & $\%$ Kadar Protein \\
\hline Ulat Sagu & $0,6624 \%$ & $0,0132 \%$ & $4,0575 \%$ \\
\hline
\end{tabular}


Analisis Kadar Protein Pada Ulat Sagu (Rhynchophorus ferrugineus) Asal Kabupaten Halmahera Timur Maluku Utara Dengan Metode Kjeldahl

PEMBAHASAN

Protein merupakan komponen penting atau komponen utama sel hewan atau manusia. Oleh karena itu sel merupakan pembentuk tubuh kita, maka protein yang terdapat dalam makanan berfungsi sebagai zat utama dalam pembentukan dan pertumbuhan tubuh. Penentuan kadar protein dalam suatu sampel di bagi atas dua yaitu nitrogen total protein dan nitrogen non protein dengan metode kjeldahl.

Salah satu limbah dari hasil panen sagu adalah batang bagian pucuk pohon yang merupakan tempat bertelurnya kumbang merah kelapa, larva dari kumbang ini dikenal dengan nama ulat sagu (Rhynchophorus ferrugineus), yang biasanya dikonsumsi oleh masyarakat Maluku dan Papua.

Pertanaman sagu di Maluku umumnya berdekatan dengan tanaman kelapa, sehingga bila telur dalam limbah sagu tersebut menetas dan menjadi kumbang dikhawatirkan dapat menjadi hama pada tanaman kelapa, larva kumbang merah kelapa dikenal sebagai ulat sagu (Rhynchophorus ferrugineus).

Ulat sagu belum dimanfaatkan secara komersial. Namun, masyarakat Papua dan Maluku yang mengusahakan pengolahan sagu sebagai sumber pendapatan, memanfaatkan ulat sagu untuk dikonsumsi. Pada daerah-daerah dengan sumber protein hewani yang sulit diperoleh, ulat sagu dapat menjadi alternatif sumber makanan berprotein tinggi.

Ulat sagu (Rhynchophorus ferrugineus) memiliki keluarga Curculionidae (Coleoptera). Ulat sagu telah menjadi hama yang paling penting bagi pohon sagu, pohon kelapa, pohon sawit, pohon palem, dan pohon kurma.

Pada penelitian ini, dilakukan analisis kandungan protein ulat sagu dengan menggunakan metode kjeldahl. Analisis kadar protein dilakukan dengan metode kjeldahl terhadap kandungan nitrogen total dan nitrogen bukan protein, dimana selisih antara nitrogen total dan nitrogen bukan protein merupakan nitrogen dari protein ulat sagu.

Kadar protein dengan cara kjeldahl dibagi menjadi 3 tahap yaitu tahap destruksi, destilasi dan tahap titrasi. Pada tahap destruksi sampel (ulat sagu) dipanaskan dengan asam sulfat pekat sehingga terjadi proses destruksi, dimana nitrogennya akan berubah menjadi amonium sulfat ((NH4)2SO4). Untuk mempercepat proses destruksi ditambahkan 
Analisis Kadar Protein Pada Ulat Sagu (Rhynchophorus ferrugineus) Asal Kabupaten Halmahera Timur Maluku Utara Dengan Metode Kjeldahl

selenium sebagai katalisator. Selenium dapat mempercepat proses oksidasi karena zat tersebut dapat menaikkan titik didih. Proses destruksi selesai apabila larutan menjadi jernih. Pada tahap destilasi amonium sulfat dipecah menjadi Amonia $(\mathrm{NH} 3)$ dengan penambahan natrium hidroksida. Amonia (NH3) yang dibebaskan selanjutnya ditangkap oleh asam borat dalam wadah penampung dalam jumlah yang berlebih. Kemudian dititrasi dengan menggunakan asam sulfat yang bertujuan untuk mengukur asam yang bereaksi dengan ammonia (NH3) kemudian ditambahkan indikator campuran metil merah dan brom kresol green. Titik akhir titrasi ditandai dengan perubahan larutan dari hijau menjadi merah kecoklatan. Analisis Kjeldahl digunakkan untuk menentukan kadar protein dalam sampel yang mengandung protein contohnya pupuk urea atau asam amino.

Pada penelitian nitrogen total diberikan asam sulfat untuk memisahkan protein dengan zat-zat kimia lainnya yang terkandung di dalam ulat sagu, atau untuk mencerna semua nitrogen, dimana untuk mencari nitrogen total harus dipisahkan dulu nitrogen dengan zat-zat kimia lain, sedangkan pada nitrogen non protein tidak diberi asam sulfat sehingga yang dicerna hanya nitrogen non protein.

Protein merupakan hasil kali dari jumlah nitrogen dalam sampel dengan faktor 6,25 , dimana faktor 6,25 berasal dari kadar nitrogen rata-rata di dalam protein adalah $16 \%$, maka protein yang terkandung di dalam sampel (gram) nitrogen adalah 6,25 $\mathrm{x}$ sampel (gram), Dimana 6,25 adalah faktor konversi nitrogen menjadi protein.

Berdasarkan hasil penelitian, diperoleh kadar protein total pada sampel ulat sagu (Rhynchophorus ferrugineus) adalah sebesar 4,0575\%.

\section{KESIMPULAN}

Berdasarkan hasil penelitian maka diperoleh kadar protein total pada ulat sagu (Rhynchophorus ferrugineus) asal Halmahera Timur Maluku Utara adalah 4,0575\%.

\section{DAFTAR PUSTAKA}

Alfonsine, C.B., 1985. Pengantar IImu Gizi, Penerbit Intan, Jakarta.

Anonim., 2011., Rhynchophorus ferrugineus.http://en.wikipedi a.org/wiki/Rhynchophorus fe rrugineus. (diakses 7 Januari 2010).

,2011.,Departemen Pertanian, Sumber Daya Alam dan Lingkungan.http://www.moa.g ov.cy/moa/da/da. (diakses 7 Januari 2011). 
Analisis Kadar Protein Pada Ulat Sagu (Rhynchophorus ferrugineus) Asal Kabupaten Halmahera Timur Maluku Utara Dengan Metode Kjeldahl

.,2011.,Merah Palm Kumbang, ferrugineus.Rhynchophorus. $\underline{h}$ ttp://cisr.ucr.edu/red palm w eevil.htm.(diakses 7 Januari 2011).

., 2011., Rhynchophorus ferrugineus.http://en.google.c om/SagoWorms/Rhynchopho rus ferrugineus. (diakses 23 Mei 2011).

Apriyantono. 1989. Analisis Pangan, Depdikbud, Direktorat Jenderal Pendidikan Tinggi Pusat antar Universitas Pangan dan Gizi, IPB.

Bustaman, S., 2008. Potensi Ulat Sagu dan Prospek Pemanfaatannya,Jurnal Litbang Balai Besar Pengkajian dan Pengembangan Teknologi Pertanian, Bogor, Jawa Barat.(http://www.smallcrab.c om/others/412-prospek-danpotensi-ulat-sagu), diakses 7 Juli 2010.

Dalita, A.Y., 2009. Sate Ulat Sagu. (http://203.89.24.62:86/News/ DisplayNews.aspx?id=12594) , diakses 5 Oktober 2010.

Edrus, N.I., dan Bustaman, S. 2009. Pengkajian Budidaya Ulat Sagu Sebagai Sumber Protein Pakan Ternak,Balai Pengkajian Teknologi Pertanian Maluku, Ambon, Maluku.(http://bbp2tp.litbang. deptan.go.id/index2.php?opti on=com content\&task=view\& id=60\&pop $=1$ \&page $=351 \&$ lte mid=137), diakses 7 Juli 2010.
Gaman,P.M., dan, Sherrington,K.B., 1994. Ilmu Pangan Edisi Kedua.Gajahmada University Press, Yogyakarta.

Mahesarani, T., 2010. Jangan Lihat Rupanya.(http://www.tnol.co.i d/id/food-clubs/5061-ulatsagu-jangan-lihatrupanya.html), diakses 21 Desember 2010

Poedjiadi, A,. 1994. Dasar-dasar Biokimia, Penerbit Universitas Indonesia (UIPRESS), Jakarta.

Riawan,S., 1989. Kimia Organik, Binarupa Aksara. Jakarta.

Saman, R.M., Sherington K.VB. 1994. Ilmu Pangan. Pengantar IImu Pangan dan Mikrobiologi. Penerbit Universitas Gadjah Mada, Yogyakarta.

Sediaoetama, A, C,. 2000. Ilmu Gizi Untuk Mahasiswa dan Profesi, Jilid I, Cetakan Keempat, Dian Rakyat, Jakarta.

Sudarmadji, dkk., 1984. Analisis Bahan Makanan dan Pertanian. Penerbit Liberty, Yogyakarta.

Suhardjo. 1999. Prinsip-prinsip IImu Gizi, Penerbit Kanisius, Yogyakarta.

Winarno, F.G., 1997. Kimia Pangan dan Gizi. PT. Gramedia Pusaka, Jakarta. 